\title{
MODTAGELSEN AF ERIK ARUPS DANMARKSHISTORIE
}

AF

\section{Thyge Svenstrup}

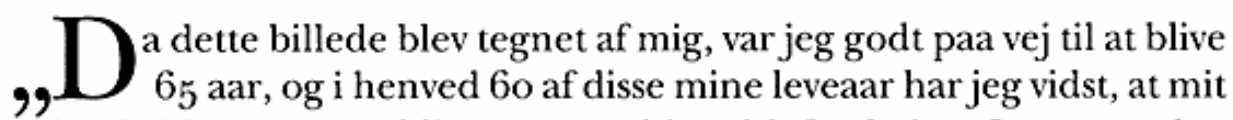
arbejde i livet maatte blive og være historisk forskning. Jeg ser endnu tydeligt for mig min far, lægen i Slangerup, staa og udpakke Cantus verdenshistorie, som fragtkonen har bragt ham fra København - det

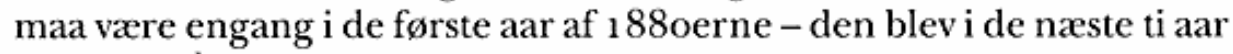
min bibel. ${ }^{1}$

Jeg levede den lykkeligste barndom og ungdom i to frisindede og aandelige hjem hos mine forældre og min mormor, der var Peter Rasmus Ipsens, terracottafabrikantens enke, hvor bevidstheden om den formende kunsts værdi kom til min kundskabssøgning.

1898 gik med besvarelse af universitetets prisopgave, et herligt aar, det første aar der helt blev brugt til selvstændig forskning. Og saa halvaaret $1^{1904-05}$ i London hos min elskelige farbror Frederik Arup, der siden 1876 havde levet i dette verdenscentrum. Jeg samlede materiale til min doktordisputats i British Museum og Record Office i Chancery Lane. Om morgenen som de andre clerks op med tophat og shagpibe paa toppen af en bus fra Chalk Farm til Tottenham Court Road Corner. Og efter dagens arbejde hjem igen i Londons taage og vidunderlige, skiftende belysninger. $\mathrm{Og}$ som denne arbejdets og forskningens tid skulde til at afsluttes, kom saa til Regents Park Road den 2 2aarige Clara Dahl lige fra det blæstomsuste Esbjerg, som hun havde set sin far opbygge, yndig, med sindet opladt for at indsuge alt, der var af aand, og ud fra sin naturlige menneskelighed en enestaaende evne til at forstaa og vinde alle mennesker for sig, af hvilken stand og art de saa maatte være. Hun blev min hustru og har i den sidste halvdel af mit liv delt alle dets glæder og storme med mig.

\footnotetext{
${ }^{1}$ Cesare Cantù ( $\left.1807-95\right)$, ita. historiker. Hans Storia universale udkom $18{ }_{3} 6 \mathrm{ff}$. med i alt 35 bd. På dansk kom $1_{71-7} 87$ bd. frit bearbejdet ved Edv. Holm og Ph. Weilbach.
} 
Med min disputats startede jeg som international historiker og havde haabet at kunne fortsætte denne linie, men verdenskrigen brød den brat af, som denne idiotkrig, som Albert Ballin² kaldte den, afbrød alle de venlige internationale forbindelser, der var bygget op fra $1871-$ 1914. Imidlertid er denne linie senere blevet taget op igen af mine bedste elever.

Der kom en tid, da jeg fik betroet statsembeder. Jeg blev arkivar i udenrigsministeriet og bragte det i orden, jeg blev departementschef og statsraadssekretær, og jeg er glad ved at kunne tro, at jeg gjorde fyldest i disse embeder. Men da Erslev engang i 1915 telefonerede til mig, at nu vilde han være rigsarkivar, og at jeg kunde blive hans efterfølger som professor, bankede mit hjærte af glæde.

Jeg har fortsat mit arbejde som kritisk historieforsker ved med mange aars mellemrum, der skyldes de nødvendige forarbejder dertil, at skrive Danmarks historie i to bind op til 1624 . Den er blevet meget haardt behandlet af ukyndig og desværre ogsaa af, som det skulde synes, kyndig kritik. Naar der engang igen bliver ørenlyd for kritisk historieforskning, vil min Danmarkshistorie faa sin tid og rette virkning.

Jeg har ofte givet udtryk for den tanke, at historikeren, for at kunne gøre sit forskningsarbejde, maa gaa ud fra en dyb sympati med og karlighed til hele menneskeheden. Historikeren maa kunne tro paa, at menneskene er en enhed, som Abraham Lincoln proklamerede, og at de vil det bedste for hverandre. Men tiderne er skiftet. Hvor der i min ungdom var glæede og samarbejde, der [er] der nu sorg og endeløst drab af menneskehed. Den forskende historiker maa kunne bevare troen paa, at dette er et forbigaaende frenomen, og at tanken om menneskenes enhed og broderlighed atter vil blive grundlaget for menneskenes samarbejde, saa at historikeren igen kan tage sit arbejde op ud fra dette grundsynspunkt."

Sådan så historikeren Erik Arup (1876-1951) tilbage på sit liv, da han engang under 2. verdenskrig nedskrev den her gengivne lille selvbiografiske skitse. ${ }^{3}$ Arup regnes for en af de betydeligste blandt vort århundredes danske historikere og står som den centrale skikkelse $\mathrm{i}$ århundredets første halvdel. Hans ry er særlig knyttet til hans Danmarks Historie. 1. bind: Land og Folk til 1282 , udkom 1. september 1925, 2.

${ }^{2}$ Albert Ballin (1857-1918), ty. skibsreder.

${ }^{3} \mathrm{Ny}$ Kgl. Samling 2874 folio. Registratur, med indledning af Inga Floto, ved forf. til narv. artikel: Historikeren Erik Arups Arkiv. Indsigt. Händskriftafdelingens arkivregistraturer. Nr. 1 . Det Kgl. Bibliotek $199^{2}$. 
bind: Standerne i Herrevalde $1282-1624,30$. september 1932. På grundlag af efterladte manuskripter i arkivet udgav Aksel E. Christensen

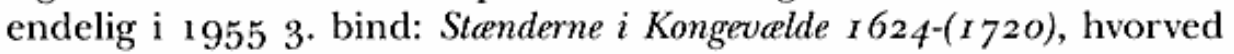
fremstillingen førtes op til enevældens indførelse. Samlet udgør de tre bind over 13 oo store sider.

Arups indgang til værket blev en stor leksikonartikel om Danmarks historie, som han marts-april 1908 udarbejdede til Hagerups leksikon (senere 1921 udgivet som udvidet og ajourført særtryk under titlen Rids af Danmarks Historie til brug for universitetsundervisningen). Artiklen fremkaldte et tilbud fra Hagerup om at skrive en lærebog til erstatning for C.F. Allens nu stærkt forældede og nationalliberalt farvede Haandbog $i$ Fedrelandets Historie med stadigt Henblik paa Folkets og Statens indre Udvikling (184o, 8. rev. udg. ved J.A. Fridericia 1881). Arup blev støttet i sin plan om at skrive en håndbog af de to af universitetets professorer, han stod nærmest, vennen J.A. Fridericia og Kr. Erslev. Uforbeholdent af Erslev, der har last leksikonartiklen med stor fornøjelse: „Den er klar og overskuelig, overmaade vel gennemtænkt, ganske som den skulde vare. Jeg forstaar meget godt, at den, som leeser den Artikel, let falder paa den Tanke, at her har vi jo Forfatteren til den meget efterspurgte Haandbog i Danmarks Historie “. ${ }^{4}$ Fridericia udtrykte sig også positivt, men havde visse forbehold og gik dybere i sin karakteristik: „De har med megen Sikkerhed, Konsekvens og Kraft trukket Linierne op for Danmarks økonomiske og delvis ogsaa dets sociale Udvikling, byggende væsenligst paa Erslevs, til Dels ogsaa paa mine Unders øgelser, og kombinerende dette med visse selvstzendige Tanker for det 17.og 18. Aarh.s Vedkommende, hentet fra Deres egen Forskning. De har derved vist, at De vistnok bedre end nogen af de yngre vil kunne gøre noget lignende for den paatænkte Haandbogs Vedkommende. Men De vil næppe selv benægte, at en saadan jo ogsaa maa tage andre Synspunkter op: rent politiske, aandelige ə: religiøse, litteræere, kunstneriske o.s.v. Hvorledes De vil kunne magte denne Side af Opgaven, giver jo Artiklen ingen egentlig Oplysning om. Og her vil jo Vanskeligheden komme til at ligge for Dem. Men jeg finder ikke, at det bør virke afskrækkende ved Deres Beslutning ... selv om de næunte Sider maa kræve en yderligere Uddybning af ikke alene Deres Studier men nxesten ogsaa af Deres Temperament og Evner".5

Planen blev dog ikke til noget med det samme, da Arup de følgende

'Erslev til A. $9 / 71908$.

${ }^{5}$ Fridericia til A. $5 / 71908$. 
år var optaget af andet arbejde. Gyldendal kom også en overgang ind i billedet; direktør Bojesen søgte at hverve Erslev og Fridericia til at skrive håndbogen; efter deres afslag henvendte han sig til Arup. Enden på sagen blev imidlertid, at Hagerup i juni 1911 tilbød Arup en kontrakt på et betydeligt honorar til udbetaling i årene 1912-16 for et værk i 4 bind på helst 5 o, højst 60 ark. ${ }^{6}$

Oprindelig skulle Arup kun skrive en hurtig afsluttet sammenfatning af de videnskabelige resultater, der var nedlagt i seksbindsværket Danmarks Riges Historie (1896-19o6), men planen blev ændret undervejs. I stedet blev det til en gennemført nyskrivning af Danmarks historie fra grunden af, der kom til at optage Arup resten af livet. Værket skulle ifølge Arups oplysninger ved udgivelsen af 1 . bind mere indgående end tidligere skildre den økonomiske udvikling, det danske folks arbejde, og betragtningen af den politiske udvikling ville blive uddybet ved, at den sås på baggrund heraf. Arup fremhævede også, at bogen var tænkt både som en fuldt ud videnskabelig lære- eller håndbog til universitetsbrug og som en bog for den store politisk og historisk interesserede almenhed. ${ }^{7}$ På de præmisser blev værket også modtaget og diskuteret, idet det blev fyldigt og indgående anmeldt såvel i dagspressen som $\mathrm{i}$ fagtidsskrifterne.

Arups Danmarkshistorie var historiografisk set et bevidst opgør i stort og småt med den traditionelle opfattelse af Danmarks fortid, der nødvendigvis måtte virke udfordrende. 1. bind af værket var den første kildekritiske syntese over Danmarks ældre historie. Det adskilte sig fundamentalt fra Joh. Steenstrups skildring i Danmarks Riges Historie. I stedet for Saxos krigs- og kongehistorie fik man, med Aksel E. Christensens ord, en rigt facetteret samfundshistorie, der stadig står som standardværket for dansk middelalder. ${ }^{8}$ Det var imidlertid ikke det, at Thyra Danebods anlæggelse af Dannevirke og jomsvikingernes bedrifter var forsvundet fra Arups Danmarkshistorie, der ophidsede sindene mest. Debatten omkring Danmarkshistorien blev et led i mellemkrigstidens opgør mellem kulturradikalisme og konservatisme, fordi Arup søgte at forene sin historieforskning med et klart personligt samfundsengagement. Med Danmarkshistorien tog Arup stilling til ikke blot fortidens, men også samtidens spørgsmål og problemer. Vær-

\footnotetext{
${ }^{6}$ Hagerups Forlag til A. $12 / 5,8 / 6$ og $14 / 61911$.

${ }^{7}$ Politiken 2/9 1925 samt Hagerups forlagsbrochure (Arups arkiv: VIII 1 b).

${ }^{8}$ Danmarks Historie I, Gyldendal 1977, s. $214^{-16}$.
} 
ket skulle yde sit til at skabe en ny samfundsbevidsthed. Hertil hjalp også værkets form og stil. I en kronikrække i Politiken mente Lis Jacobsen at kunne konstatere, at Arups Danmarkshistorie ikke henvendte sig blot og ikke mest til historikere af fag, men til hele det store, læge publikum. Hans Danmarkshistorie var anlagt som „folkelig historieskrivning“, uden kilde- og litteraturhenvisninger, uden vilje til at diskutere afvigende synspunkter, og holdt i en absolut, autoritativ tone, som den var. ${ }^{9}$ De fleste af anmelderne var også enige om at lovprise Arups sprog og stil. Hans Danmarkshistorie var et „helstøbt“ værk, der kunne læses som en roman, man ikke lagde fra sig, før man var færdig!

Anmeldelserne i dagspressen af Arups Danmarkshistorie er hidtil ikke eller kun perifert blevet behandlet, også fordi de kun i så begrænset omfang har været kendt. De giver udtryk for politiske og sociale holdninger, en første, personlig stillingtagen. I den egenskab har de betydelig ideologihistorisk interesse som kilde til mellemkrigstidens holdninger. Hertil kommer, at de også har realkritisk interesse, fordi de i mange tilfælde var skrevet af historikere, der havde eller fik et solidt navn i dansk historievidenskab. For Harald Nielsens og Henning Kehlers vedkommende er sagen en anden, men ud fra en mentalitetshistorisk synsvinkel påkalder deres anmeldelser sig ikke mindre interesse, idet de begge havde indflydelsesrige stillinger som konservative kulturpersonligheder. Unders $ø$ gelsen er begrænset til hovedsagelig at omfatte de anmeldelser, som Arup selv har fundet det værd at opbevare i sit arkiv. En samlet oversigt over de anmeldelser, som artiklen bygger på, er givet i medfølgende bilag.

\section{Dagbladskritikkens modtagelse af 1 . bind}

Debatten i dagspressen vidner om, at både Arups modstandere og tilhængere havde blik for de ideologiske og politiske perspektiver i hans Danmarkshistorie. Historikeren Hans Jensen udtrykte det klart i en meget velvillig anmeldelse af 1 . bind i Venstre-avisen København: „Det tjener til Ros mere end til Dadel for den foreliggende Bog, at den i saa stor Udstrækning bærer Præg af sin Forfatters stærke Leven med i hans egen Tids Samfundsspørgsmaal“, hedder det her. Arup kunne ikke lide Saxo og hans Gesta Danorum, der forherligede hird og militær, og som desuden havde været „en fundgrube for al den danske nationalfølelse,

${ }^{9}$ Politikens kronik 22/1 1926. 
der særlig er bestemt ved uviljen mod andre folk, først Tyskerne, men dernæst Nordmænd og Svenskere ${ }^{\prime 10}{ }^{10}$ Hans Jensen havde som de øvrige af anmelderne øje for denne side af værket $\mathrm{g}$ fremhævede, at det var de fredselskende konger, Arup sympatiserede med: Den hos Saxo så lidet agtede kong Niels (1104-34) er ifølge Arup en forstandig og folkelig monark, der respekterer den offentlige mening og kun vil regere $\mathrm{i}$ samstemning med folket. Han vinder velfortjent popularitet ved ,at imødekomme det Ønske“, siger Hans Jensen, „der hos Datidens Folkehøvdinge - ikke for ingenting Landsmænd af vore moderne Rigsdagspolitikere - har gjort sig gældende ikke just om ligefrem Afrustning, men dog om en alvorlig Nedrustning“. „Man faar af den Skildring af Kong Niels, der her er givet“, fortsætter han, „det Indtryk, at han og Viggo Hørup ikke vilde have haft svært ved at forstaa hinanden."

Arups værk betegnede ifølge Hans Jensen „en Landvinding for den strenge historiske Kildekritik “ og et dristigt fremstød for en gennemført „radikal-realistisk Betragtningsmaade“ af Danmarks ældste historie. Hans bog samlede sig om de danske landsbybønders fredelige arbejde for at gøre sig den danske jord underdanig. Arup mente, at landsbyen, som han anså for kernen i Danmarks historie, var opstået som resultat af hjulplovens indførelse her i landet omkring år 5 oo e. Kr. Denne effektive, men tunge plov var de danske landsbybønder nødt til at slutte sig sammen om i passende antal for at anskaffe, hvoraf fællesdriften af landsbyjorden fulgte, ligesom mange hundrede år senere i $1800-t a l l e t$ efter centrifugens opfindelse om oprettelsen af et mejeri: „Andelsbevægelsen paa denne Plads i dansk Samfundsudvikling“, udbryder Hans Jensen, „det er unægtelig en forfriskende Tanke“. Det blev hos Harald Nielsen ikke uvittigt til, at andelsbevægelsen allerede én gang, i den grå oldtid, havde reddet landet ud af en økonomisk krise! $!^{11}$

Kr. Erslev anmeldte bind 1 meget anerkendende, men ikke ubetinget positivt i Politikens kronik allerede 15 . september $19^{2} 5$. Det var en meget ,saglig“ anmeldelse i den forstand, at han (som også Arups nære kampfaller Edv. Bull og Curt Weibull) forbigik Arups ideologiske synspunkter og betydningen heraf for hans historiesyn. Erslev roste Arup for „med stor Konsekvens og energisk Skarphed“ at have gennemarbejdet Danmarks ældre historie som den første på grundlag af „systematisk Kildekritik“. Når Arups Danmarkshistorie var blevet så forskellig fra tidligere tiders, skyldtes det også den vægt, Arup havde lagt på

\footnotetext{
${ }^{10}$ Arup: Danmarks Historie I, 1925, s. 261 f. (i det flg.: DH I).

"Nationalidende 13/2 1926.
} 
at få „Samfundsudviklingen“ frem. Ved at lægge tyngdepunktet her var han „i fuld Overensstemmelse med moderne Historieskrivning“. Men Erslev kritiserede også Arup for, at han ikke selv altid pegede på eller advarede læserne om, at her var man ikke på sikker grund. Som eksempel anførte han Arups opfattelse af, at det efter $125^{\circ}$ er kongens kansler, der har den afgørende indflydelse på regeringen - nærmest $\mathrm{i}$ lighed med det 19. og 20. århundredes parlamentariske stats- og premierministre - mens kongerne træder helt i baggrunden. Dette blev for Erslev et eksempel på, „,hvorledes selv en kritisk Historiker kan blive helt tryllebundet af sin egen Gretning“, og ogsaa andetsteds vover Arup sig saare langt ud“, tilføjede han. Den forventede håndbog for lærere og studerende var det ikke blevet, men et skrift, der fyldigt viste, „hvorledes Udviklingsgangen i Danmarks Historie tegner sig for en højtbegavet Historiker, der med grundigt Studium forener stor Evne til at forstaa Sammenhæng.“ Med sine "mange ny Synspunkter“ ville bogen give historikerne „rige Impulser“.

I sin anmeldelse i Social-Demokraten bemærkede Albert Olsen, at selve Erslev allerede havde sagt god for værket, og at Arup så for så vidt kunne være ligeglad med den øvrige kritik. Der tog Albert Olsen nok munden for fuld. Et par år senere skrev Erslev til Arup, i forbindelse med et forsøg på at få denne indvalgt i Videnskabernes Selskab, at der i $19^{2} 5$ havde vist sig „mere angribeligt" i Arups 1 . bind, end han havde troet. Over for det følgende bind ville Erslev imidlertid kunne betragte sig selv som den mest sagkyndige. ${ }^{12}$

Albert Olsen fremhævede, at det især var „de sociale og økonomiske Forhold“, Arup havde gjort til genstand for sine undersøgelser. Vikingen blev ikke slagsbroderen, men udvandreren, som forholdene tvang hjemmefra. Derimod blev krigshistorien og de "store“ begivenheder, der var blevet pisket ind i de fleste gennem „en Række umulige Danmarkshistorier“, "skubbet ud i den Baggrund, hvor de med Rette hører hjemme." Kongerne og stormændene og deres bedrifter blev omvurderet, idet Arup havde et skarpt øje for, at Saxo og de andre historieskrivere i virkeligheden kun var "kongelige Lakajhistorikere“. Enhver, der havde blot „en Smule social Interesse“, burde derfor læse Arups bog. Albert Olsen sluttede af med et ønske om, at skolebøgerne snart måtte blive revideret efter Arups principper: „Som Skolebøgerne er nu giver de Lærere, som ønsker det, Adgang til mere eller mindre skjult chauvinistisk Agitation. Dette vil være en Umulighed med Be-

\footnotetext{
${ }^{12}$ Erslev til A. $3^{1 / 1} 19^{27}$.
} 
nyttelse af Arups Synspunkter som Grundlag for Skolebøgernes Udarbejdelse."

I det kommunistiske Arbejderbladet fik Arups bog i april 1926 en begejstret anmeldelse, idet bladet fremhævede en række af Arups centrale synspunkter og holdninger, naturligvis i en fortolkning læserne kunne identificere sig med. Anmeldelsen var signeret e-n., efter al sandsynlighed Ernst Christiansen, der fra 1926 var bladets redaktør. Danmarkshistorien blev præsenteret under overskriften: „Ny og sandfærdig Danmarkshistorie. En betydningsfuld Bog af Professor Erik Arup.“ Anmeldelsen tog fat, hvor Albert Olsen havde sluppet: „En af de Maader, hvorpaa den kapitalistiske Stats Skoler forgifter den opvoksende Slægt, er en fuldstændig falsk og heltigennem nationalistisk og militaristisk Gengivelse af Danmarks Historie." Arups bog betegnedes som „et stærkt Slag“ mod denne officielle Danmarkshistorie. Helt tilfreds var anmelderen imidlertid ikke med de agrarhistoriske dele af fremstillingen. Ganske vist mærkede man "nye Synspunkter" allerede ved Arups skildring af landsbyernes grundlæggelse: I disse „smaa Fællessamfund“ mødte man straks „Modsætningen mellem den enkeltes Ejendomsret og den fælles Ejendomsret". Arup havde imidlertid hævdet, at almindingen var fri jord for alle, men at en mands arbejde med jorden skabte privat ejendomsret til den for ham og hans arvinger. Noget „afgørende Bevis“ for denne opfattelse førtes dog ikke efter anmelderens mening. Landsbyfællesskabet omfattede ifølge Arup „den arbejdende Befolkning“, mens „Overklassen“ byggede „deres store Boliger for sig selv“ og levede „paa Trællearbejde“. Arups skildring af trællenes stilling og deres rekruttering var „noget summarisk“, måtte anmelderen mene, og fremstillingen af træellevæsenets afskaffelse omkring år 1200 „endnu mere summarisk“.

Den egentlige betydning af bogen lå ikke i skildringen af dagliglivet og landbrugets forhold. Derimod i „den totale Omvurdering“, Arup underkastede vikinge- og Valdemarstiden. Med Arups æggende ord, der citeredes: „Betydningsfuldere for Danmark end hele Englands Erobring var det, at om ved Aar 1000 begyndte Befolkningen ved Øresund i større Omfang at fiske Sild i Sundet." Tilsvarende kunne anmelderen også ganske tilslutte sig Arups vurdering af borgerkrigene i 1 1oo-tallets midte mellem Svend, Knud og Valdemar - der ifølge anmeldelsen spillede en så stor rolle i skolens fædrelandshistorie - som „Overfladen af Danmarks Historie“, udspillet blandt „de faatallige Kredse af en Overklasse“, der kun fik den betydning, , at de ødelagde, hindrede eller forsinkede det danske Folks Arbejde“. Anmeldelsen 
konstaterede med tilfredshed, at Arup derimod udførligt skildrede den fremgang, landbruget havde i samme periode, og at han endog havde viet en enkelt bonde særskilt omtale. Den med Arup så berømte Bjørn fra Suserup, der i kamp og trætte med munkene ryddede nyt land, og hvis vita Arup havde rekonstrueret på grundlag af Sorø Klosters gavebog, og som han satte det eftermæle i sin Danmarkshistorie, der irriterede så mange af hans konservative modstandere: „Det var Mænd som Bjørn og hans Sønner, der i hin Tid gjorde Landet rigere ved deres Arbejde; og deres Gerning fortjener nok saa meget at mindes af Historien som deres, der gik paa Korstog mod Vender eller Ester med Absalon eller Andreas Sunesen."

Arbejderbladet fandt, at disse ord kunne sættes som motto for hele Arups bog: „Paa Basis af en materialistisk Historieopfattelse sættes det produktive Arbejde i første Linie, medens de dynastiske og imperialistiske Overklassekrige berøves deres forlorne Glans. "Arups bog betegnede i dansk historieforskning "trods sin Svaghed paa enkelte 'sociale' Punkter" noget helt nyt. Det var derfor heller intet under, at „Borgerskabet og dets Presse" var faldet over bogens forfatter. Men jo stærkere disse angreb måtte blive, „desto stærkere bør til Gengæld Arbejderkredse give Forfatteren sin Tilslutning “, thi forhåbentligvis ville Arups følgende bind op til nutiden benytte samme vurderingsmåde. Anmelderen mente endelig, at det ville være en virksom måde at støtte denne historieopfattelse på, at lade alle kommuner med „Arbejderflertal" beordre Arups bog anvendt som grundlag for lærernes undervisning. Og alle „ældre Arbejdere“ burde også selv læse denne bog, der i populær form gav „en sandfærdig Fremstilling af det danske Lands og Folks Historie."

I Ribe Stifts-Tidende anmeldte Jørgen Olrik bogen 14. september $19^{2} 5$. Han betegnede dens afsnit om den sociale, retslige og økonomiske udvikling som "ypperlige og fulde af originale og ofte meget træefende Skildringer". Men man kunne ikke være blind for „Ensidigheden“ i værket. Arup interesserede sig i virkeligheden næsten udelukkende for udviklingen af „det fredelige agerdyrkende Samfund“, mens han gik meget flygtigt henover de ydre tildragelser, navnlig alt hvad angik krig og fejde. Man kunne derfor også føle sig fristet til at betegne Arup som en art „Antikrigshistoriker“, hvis „pacifistiske Synsmaade" medførte en fuldstændig omvurdering af de ledende politikeres og særlig kongernes styre, der næppe ville blive stående uanfægtet. Denne omvurdering hang sammen med, at Arup næsten helt savnede sans for "det heroiske Element“ i historien. At det danske rige 
„sikkert“ var opstået „ved krigersk Erobring“ i folkevandringstiden, fik man ikke et ord at vide om i hans Danmarkshistorie, mens omvendt samtidens jyske folkestammer omhyggeligt blev opregnet og henført til den landsdel, hvor de hørte hjemme. Arup syntes i nogen grad at undervurdere "Kongemagtens“ og "det aristokratiske Elements" betydning for rigsenheden i oldtid og middelalder. På samme måde var Arups vurdering af Saxo, „vor Middelalders store Historiker“, også stærkt præget af hans ensidige og uvillige opfattelse af alt, hvad der hed "Hærmandssynspunkt og Hærmandstroskab mod den kaarede Konge“, skønt Saxos værk netop var et slående eksempel på, hvordan „en virkelig Nationalfølelse" havde udviklet sig på grundlag af hirdmandsfølelsen over for kongen. At Valdemarstidens nyskabte nationalfølelse ytrede sig stærkt i form af uvilje mod nabolandene, var der ingen grund til at tage Saxo så ilde op, som Arup syntes at gøre: „det samme er Tilfældet overalt, hvor et Folk nylig er blevet sig sin Ejendommelighed som Nation bevidst", indvendte Olrik.

Et par dage senere gav Povl Engelstoft i Sor AmtstidendeArups bog en udførlig og anerkendende, men på vigtige punkter forbeholden anmeldelse. Han karakteriserede først Arup som „en af de klareste og mest stringente Begavelser" blandt samtidens danske historikere: „Udviklingstanken, den marxistiske Opfattelse af Historiens Begivenheder som Udslag af Folkenes materielle Kaar, endelig en hensynsløs Gennemførelse af den historiske Kildekritik, der fejer alle usikre Overleveringer og nationale Trossætninger til Side - dette er Historikeren Arups Rustning“. Hvis en og anden alligevel ville give rum for „en beskeden Tvivl" om, hvorvidt Arup var i stand til at skrive Danmarks historie, var det kun, fordi forsættet var så stort: „Et Folks Historie spænder saa usigelig fast om Nutid og Fremtid, at den, der fortæeller den, har Brug for en aandelig Samfølelse med alt dansk, som i og for sig ikke erhverves gennem historisk Studium“. Imidlertid havde Arups sigte været at skrive en oplysende håndbog med det mål „at forklare, ikke vække, med en Saglighed, for hvilken baade Anekdoter og den nationale Opdrift forsvinder", mente Engelstoft. Overalt i Arups fremstilling sås „Udviklingen indefra og nedenfra, fra Folket opefter“. En hyppig tilbagevendende modsætning $i$ hans skildring var modsætningen mellem "den krigerske Overklasse“ og "den store Bondemasse“. Arups bog var ikke mindst „Menigmandens“ historie i Danmarks ældste tid. Heri lå "en meget stor Fortjeneste", for det var de senere tiårs fortjeneste, at forskningen havde „vendt sig bort fra Taarnene i Udviklingen og søgt at grave ned i Masserne“. Når det derimod gjaldt 
Arups syn på fyrster og stormænd, deres politik og krige, var hans forklaringer og resultater imidlertid ikke hævet over tvivl: „I sin fuldkomne Fjernhed fra den Historieskrivning, der først og fremmest arbejder med Personer, Idéer, Dynastier, Programmer “ turde Arup „til Tider komme for langt over i Modsætningen“, mente Engelstoft.

Som intermezzo kan man betragte den strid, der udkæmpedes mellem Lis Jacobsen og Erik Arup i januar 1926 i en række kronikker i Politiken om et så tilsyneladende ufarligt emne som de danske runeindskrifters karakter. Lis Jacobsen, som Arup selv radikal, lagde ud med i nogle "Lægmandsbetragtninger" at betegne Arups Danmarkshistorie som „apriorisk Historieskrivning“. Arups „suveræne“ forhold til kilderne fandt filologen Lis Jacobsen særligt udtrykt $\mathrm{i}$ hans behandling af vikingetidens runeindskrifter. Det var et emne, hun selv kunne udtale sig om med sagkundskab, idet hun i 1913 havde udgivet en håndbogsudgave af Ludvig Wimmers De danske Runemindesmerker. I forordet havde hun taget forbehold over for Wimmers runelæsninger og -fortolkninger, uden at Arup havde taget hensyn hertil. Han havde i runestenenes vidnesbyrd ment at finde fortrinsvis lovprisning af det danske landbrug og udtryk for de hjertelige følelser mellem mennesker: „Skulde man imidlertid dømme efter indskrifterne paa runestenene fra 9. og 10. aarh. i Danmark, vilde man tro, at disse aarhundreder alene var viet til det fredelige landbrugs fremskridt i Danmark; saa yderligt faa er de runesten, der vidner om vikingefærd. De fleste taler om landbrug eller personlige forhold", siger han i Danmarkshistorien. ${ }^{13}$ Lis Jacobsen hævdede mere traditionelt, at runestenene tværtimod talte om kamp og krigerfærd. Arup forsvarede sig i en kronik med den ikke helt heldige titel Lille Svar til lard Frue, og i maj samme år rykkede tilmed den højt meriterede professor Finnur Jónsson ham til undsætning med en kronik sammesteds (De danske Runeindskrifters Karakter), der igen fremkaldte replik fra Lis Jacobsen (Vikingetidens Runestene) og duplik af Finnur Jónsson, uden at nogen af parterne gav sig. Men at Lis Jacobsen virkelig havde haft fat i den lange ende, tør man slutte af en udtalelse, Arup var citeret for omkring udgivelsen af Danmarkshistoriens 2. bind. Heri blev han refereret for, at han „muligt nok" ville „revidere“ sin af Lis Jacobsen så hårdt angrebne runefortolkning, hvis der skulle komme et nyt oplag af 1 . bind. ${ }^{14}$ Omvendt kunne Lis Jacobsen en måneds tid senere med henblik herpå takke Arup for, at

\footnotetext{
${ }^{13} \mathrm{DH}$ I, s. 108.

${ }^{14}$ Jyske Tidende og Kolding Avis 1 /9 1932.
} 
han i en eventuel ny udgave ville tage hensyn til hendes kritik af Wimmer: ,Jeg er iøvrigt nu klar over-men var det ikke dengang - at jeg $i$ alt for høj grad bebrejdede Dem en opfattelse, hvor De maatte have ret til at bygge paa den daværende autoritative sagkundskab“, føjede hun udglattende til efterfulgt af en udtalelse med større perspektiv, som må have glædet Arup: „ogsaa paa et andet punkt, og et væsentligt punkt, fortryder jeg nu min kritik, nemlig deri at jeg ikke tilstrækkeligt indsaa og fremhævede værdien af det nye helhedssyn, De giver paa Danmarkshistorien " ${ }^{15}$

Arup havde fundet, at særlig en bestemt runesten, Sønder Vinge stenen, med Wimmers rekonstruerede tekst, støttede hans opfattelse af vikingetidens fredelige karakter: ["Tovi bryde rejste denne sten efter sine brødre Yre og Kade.] Sæl den, som pløjede og saaede i sin ungdom, det vil sikkert give rigt udbytte ${ }^{16}{ }^{16}$ Realkritikken må der her ses bort fra. Lis Jacobsen ville læse den samme tekst: ["Tovi bryde rejste...] Men Are saarede og øvede Sejd; usæl han mon evig være ${ }^{\text {. }}{ }^{17}$ Derimod tør det formodes, at Arups betoning af, at just denne indskrift „som i en sum“ samlede „det dybeste og bedste af det danske folks livsvisdom dengang og til alle tider", særlig har vakt Lis Jacobsens irritation. Arups Danmarkshistorie var nemlig efter hendes opfattelse et „prægnant Udtryk for en bestemt Aandsretnings Syn paa Historien, den materialistiske.“ Denne åndsretning gik dog vel nu „stærkt paa Hæld“, fordi man „ved Dag ud og Dag ind at høre Materialismen i Rigsdag og andet offentligt Liv prist i den evige Lovsang om de danske Smørfjerdinger og de danske Flæskesider", som landet skyldte sin rigdom, var blevet mæt. Derfor var der nu også i tiden efter Lis Jacobsens mening en trang til en „Ideal-Historie“, som ikke skulle være „Bondekarlens og Skovhuggerens og Sildefiskerens“ historie: „Vi vilde snarere have vakt til Live de Helteskikkelser, der, om end kun for en Tid, gjorde Landet større og gav dets Sønner mod til Langfart og Daad." Materialismen havde indpodet folket at skyde alle de vilde fugle for at skærme lam og høns. Men nu længtes man efter igen at se „Kongeørnens Flugt over Landet“. Bedre end „Ideal-Historie“ var dog „virkelig Historie“, der måtte skildre

\footnotetext{
${ }^{15}$ Lis Jacobsen til A. 26/9 1932. Helhedssynet, som ingen af Arups videnskabelige anmeldere diskuterede, er analyseret af E. Ladewig Petersen: Omkring Erik Arup: Struktur og granser i moderne dansk historieforskning (ca. 1885-1955). Historisk Tidsskrift bd. 78,1978 , s. $141-46$.

${ }^{16} \mathrm{DH}$ I, s. 109.

${ }^{17}$ Politikens kronik 23/1 1926.
} 
„baade Bondens og Høvdingens Betydning, baade Erhvervets og Digtningens og Heltelivets". At lade som om, alene bonden og kræmmeren havde arbejdet for landets tarv, mens Knud den Store og Absalon kun havde haft egennytte for øje, var efter Marcus Rubins datter, Lis Jacobsens, opfattelse urigtigt: „thi - som et talmudisk Ord lyder - 'man skal heller ikke bøje Retten til Fordel for den Fattige'“. ${ }^{18}$

Hovedangrebet på Arups Danmarkshistorie kom fra de to konservative kritikere Henning Kehler og Harald Nielsen. I sin anmeldelse i Kristeligt Dagblad drøftede Kehler indledningsvis med klar adresse til Arup, om der var tilstrakkelig grund til „at bryde med den folke- og fædrelandshistoriske Tradition " $\mathrm{i}$ historieskrivningen, hvis den kildekritiske prøvelse kun førte til „et rent negativt Resultat“, hvad ofte skete. Hvis opgivelsen af traditionen i praksis førte til „den største Vilkaarlighed, til rent subjektivt farvet Gætteværk “, hvis man i stedet for „repræsentativ Historieskrivning “ blot fik ,subjektivt Kaos og Anarki“, var intet vundet, men meget tabt, anførte Kehler med henvisning til den konservative historiker Joh. Steenstrup.

Grundsynet i Arups Danmarkshistorie prægedes af „den materialistiske Historieopfattelse“. Arup „tophuggede“ „uden Fortrydelse“ historiens berømte skikkelser. Han syntes at have kastet et blik på sin samtid, „en politisk Afmagtstid“, og fordi han ikke der havde truffet „Personligheder i stort Format", havde han sluttet, at der heller ikke havde veret nogen i Valdemarstiden. Men det var Valdemar den Stores og Absalons personlighed i forening med forholdene, der havde skabt rigssamlingen i det 12 . århundrede og en dansk nationalbevidsthed. $\mathrm{Og}$ den sjællandske Hvideslægt bragtes i hans Danmarkshistorie især i erindring for „den ejendommelige Oplysnings Skyld“, at den byggede kirker „paa Spekulation“" „Saaledes vil den materialistiske Historieskrivning altid lægge en Hovedvegt paa de laveste Motiver.“

Vurderet ud fra dets egne begrænsede forudsætninger havde værket imidlertid også positive sider, fandt Kehler. Han fremhævede således Arups skildring af landbrugets og bondestandens historie, som dog allerede Allen havde lagt hovedvægten på. Men han kom også med den bemærkning, at hvor Allens skildring af bonden stod i samklang med "den liberale Enevæeldes milde og omsorgsfulde Humanisme for det vigtigste af Befolkningens Lemmer“, på trods af angrebene på Frederik VIs tid, der var Arups fremstilling farvet af „den demagogiske Romantik, som brød frem ang. Synet paa Bonden i Provisorieaarene - især

${ }^{18}$ Politikens kronik 25/1 1926. 
takket være Hørups litterære Iscenesættelse af Kampen mellem Vadmel og Træsko paa den ene Side og den nationalliberale og konservative Guldtressekasket og Diplomatfrakkethed paa den anden“. For Allen var bonden endnu „Almue“, men for Arup „Stridsmand“.

På „afgørende Punkter“ i Danmarkshistorien viste Arup dog „en Mangel paa historisk Realisme og en Blottethed for vital politisk Sans", som ville have været forfærdende, hvis ikke „den historiske og politiske Radikalisme“, han typisk tilhørte og repræsenterede, havde hærdet læseren til overmål. Kehler fandt, stadig ganske træffende, at det sikkert nok ikke var kildekritik alene, der havde fået Arup til at foretrække Roskildekrønikens politiske tendens fremfor Saxos i Gesta Danorum: Arups valg beroede på ,hans egen politiske og ideologiske Indstilling“. Absalon var ikke Arups helt, for han ,vilde utvivlsomt have forudset Verdenskrigen" og ikke "fortabt sit Mod i Troen paa en tre Maaneders Sejr for Tyskerne“, „ikke have været i Tvivl om, hvilket Udfald af Krigen der tjente Danmarks sandt forstaaede Interesser: det danske Folkelivs fortsatte Bestaaen paa Historiens danske Land indenfor een national Rigsgrænse“. Arups helt var derimod den nu så velbekendte kong Niels, hvad Kehler ikke kunne billige: „Kong Niels er i Arups Opfattelse en Forløber for Laust Rasmussen og P. Munch. Han er i helt moderne Forstand Afrustningsmand. Hans Politik er en Illustration til Valgsproget: 'Hvad skal det nytte!'“

Kehler gjorde i Kristeligt Dagblad også indvendinger mod Arups „Mangel paa Forstaaelse“ for kristendommen og dens betydning for dansk folkeliv og kultur. Arups konservative kritiker havde også et godt øje til hans syn på kønsmoralen. Ikke helt med urette ud fra den betragtning, at kampen for en friere kønsmoral var et vigtigt punkt for Georg Brandes, sammen med Viggo Hørup dansk radikalismes fader.

Kehler sluttede sin anmeldelse med at erklære Arups Danmarkshistorie for død og „forældet“, hvad angik dens „almindelige Synspunkter, Meninger og Fordomme“. ,Moderne“ville den have varet for 25 år siden, hvori der lå en finte til Arups ,politiske Naivitet“ $i$ almindelighed og til ministeriet Zahles forsvars- og udenrigspolitik før og under 1. verdenskrig i særdeleshed.

Kehlers to kronikker efterfulgtes i februar 1926 af et angreb på hele fem kronikker af Harald Nielsen i Nationaltidende. De blev dels straks bragt også i Dagens Nyheder, dels senere i august samme år udgivet af Nationalfonden for Konservatismen i Danmark som særtryk under titlen Radikal Videnskabelighed, nok for at advare mod den formodede fare, Arups radikale historieskrivning kunne udgøre for ungdommen 


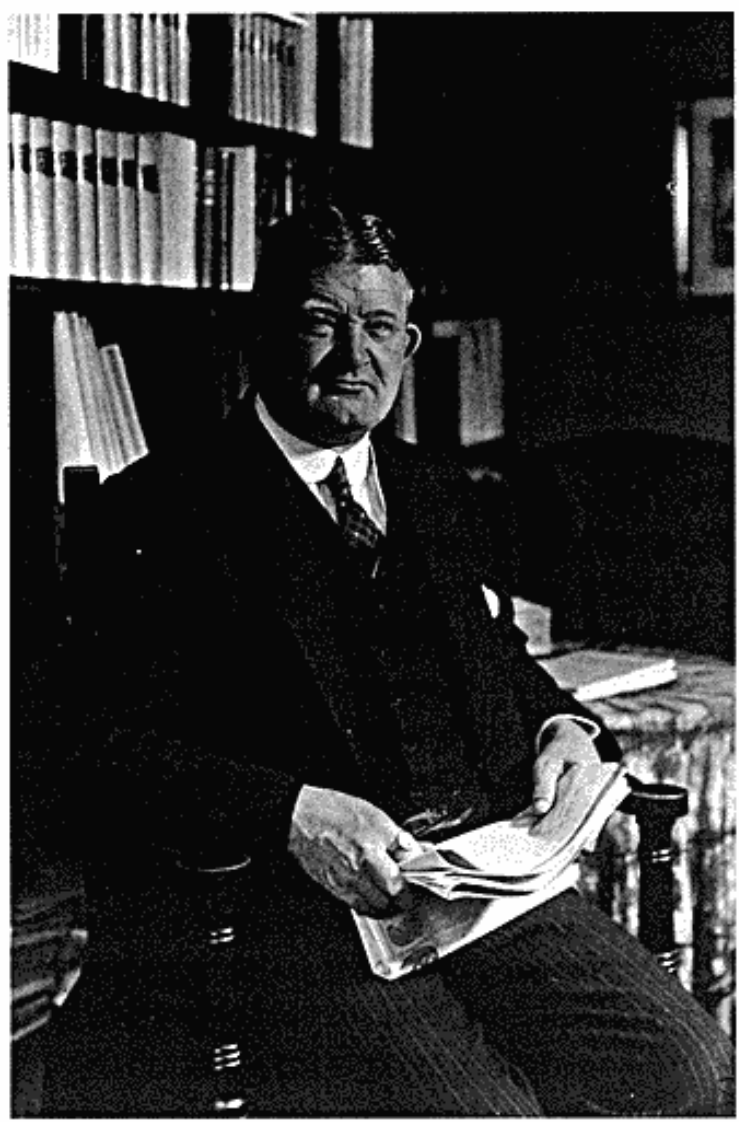

Professor Erik Arup (1876$1951)$ ved halvtredsårsdagen, omkring udgivelsen af 1 . bind af Danmarkshistorien 1925

og den sunde nationalfølelse. Men hermed var det endda ikke helt slut, idet Harald Nielsen også lod sine betragtninger optrykke i bogen Selvforsvar og Landevern (1927).

Meget var imidlertid allerede sagt da. Af interesse er isæer de angreb, Harald Nielsen rettede mod Arups forsøg på at skrive en mere folkelig og demokratisk Danmarkshistorie. Harald Nielsen fandt, at denne bestræbelse ikke var så ny endda, det ny lå derimod $\mathrm{i}$, at Arup med sin skildring havde haft en „Bagtanke“, der ikke var til at tage fejl af. Han havde overalt søgt at fremhæeve „de stille i Landet" på bekostning af "de banebrydende Personligheder", dem der ikke havde interesseret sig for „de høje eller dybe Ting“, som de alligevel ikke forstod sig på, men som havde passet deres dont uden at bryde sig om, hvad de store herrer kunne finde på. Men denne Arups 'menigmandige' (et ærke-nationalliberalt udtryk!) opfattelse var falsk og ensidig. Tronstridighederne mel- 
lem Svend, Knud og Valdemar i 1 1 oo-tallet var ikke kun „Overfladen af Danmarks Historie“, der alene ødelagde, hindrede eller forsinkede den danske bondes trofaste arbejde med den danske jord. Disse stridigheder gjaldt spørgsmålet om, „under hvilke Vilkaar“ den danske bonde i fremtiden skulle gøre sit arbejde.

Til fremhævelsen af folket svarede den konsekvente reducering af kongernes magt og indflydelse. For Arup var kongerne alle „lige smaa“, ingen af dem havde betydet meget og sjældent noget heldigt. Derfor havde han også frataget dem deres gamle tilnavne og nummereret dem, hvad Harald Nielsen så som et led i Arups ngennemførte Demokratisering" af Danmarkshistorien. Henning Kehler talte tilsvarende i sin anmeldelse om, at dette kun var tæenkeligt i "Talparlamentarismens" tid. Men i øvrigt beklagede næsten alle Arups anmeldere denne forandring, det hæmmede bogens anvendelighed. Også Erslev, der kaldte det „en kedelig Manér“. For Arup var der imidlertid næeppe blot tale om drilleri og håndfast demokratisering. Den, der bedst forstod hans hensigt med den så irriterende lille andring, var Johs. V. Jensen, der anmeldte Danmarkshistorien i en dobbeltkronik i Social-Demokraten: „de tidlige danske Konger fremtræeder herved som om man hørte om dem for første Gang“, siger forfatteren, ,ikke som en Klang der hænger sammen med en uundgaaelig Tradition, men karakteriseret paany gennem hvad de var og hvad de foretog sig“. Arup ville vaske tavlen helt ren, for at traditionsopgøret kunne sætte sig igennem.

Valdemarernes tidsalder var traditionelt blevet betragtet som en glansperiode $\mathrm{i}$ dansk historie, fortsatte Harald Nielsen, men ikke i Arups Danmarkshistorie. Valdemarernes nordtyske udenrigspolitik førte nemlig blot til skuffelser og nederlag efter hans fremstilling og indgav „for lange Tider de førende Mrend i dansk Politik en ulykkelig Tro til, at Danmark kunde hævde et Herredømme over Landene paa den anden Side af $\varnothing$ stersøen “. Eller i Harald Nielsens precise tolkning: „Dumhederne fra $184^{8-64}$ om igen“. „De ledende Mænds Fejl“, skrev Arup, blev imidlertid „opvejet ved de store Fremskridt, der samtidig fandt Sted i dansk Landbrug og dansk Erhvervsvirksomhed i det hele taget", hvad Harald Nielsen ondskabsfuldt, men vel rammende, betegnede som „den kære stadige Tanke, der er Bogens Ledemotiv.“ „Men“, indvendte Harald Nielsen, „hvorledes vilde det være gaaet med disse Fremskridt, hvis Landets Grænser ikke var blevet sikret, hvis Kongemagten ikke havde skabt Ret og Orden og Sammenhold, og hvis Folket ikke var bleven fyldt af Tro paa sig selv og sin Fremtid og af Villie til Fremgang? Vilde Danmark overhovedet have eksisteret eller eksi- 
steret i samme Omfang som nu, hvis Valdemarerne ikke havde ført den Politik, der her stemples som kortsynet og forfejlet?"

Som helhed taget kan Harald Nielsens indlæg ikke karakteriseres som vulgærkritik eller som perfidt, heller ikke Kehlers anmeldelse i $1925 .{ }^{19}$ Meget var imidlertid ubehageligt og tonen helt igennem slet. I den afsluttende kronik: „Sandhedens Apostle“ karakteriserede Harald Nielsen Arups Danmarkshistorie som et produkt af en fornuft, der havde indgået forbund med „Forræderiet“. „En tør, fattig, rodløs Fornuft“, der var „frigjort" „navnlig for de Følelser og Fordomme, der har deres Rod i Forkærlighed for sit eget Land“. Det er toner, der kendes fra konservativ polemik mod Georg Brandes, og på dette område var Harald Nielsen kyndig, for så vidt som han et par år $\mathrm{i}$ forvejen havde udgivet Brandes-bogen Usurpatoren (1922), i den seneste store litteraturhistorie karakteriseret som et „,kamskrift $“{ }^{20}$ Han sluttede af med at betegne Arups Danmarkshistorie og de positive reaktioner på den som „falmet Radikalisme“ og radikalt „Klikevæsen“ på universitetet og i den videnskabelige verden.

\section{Dagbladskritikkens modtagelse af 2. bind}

Anden del af Arups Danmarkshistorie udkom 3o. september 1932. Den blev anmeldt 2. oktober af Politikens redaktør Vald. Koppel. Formentlig fordi bladet ikke havde formået at få nogle af Arups kolleger til at gøre det, selv om der dog var gode trofaste støtter af det radikale parti blandt dem, som Henning Kehler maliciøst mente. ${ }^{21}$

Koppel brugte god plads på de mange om- og nedvurderinger $\mathrm{i}$ Arups Danmarkshistorie, der vakte sådan opsigt: "Justitsmordet“ på Marsk Stig. Niels Ebbesens drab på grev Gert, et „politisk Mord“, der lige så lidt som andre politiske mord i verdenshistorien kunne forandre „de politiske Begivenheders naturlige Gang". Dyveke, Christian IIs elskerinde, som „højst sandsynlig“ døde af blindtarmsbetændelse o.s.v. Det var provokerende meninger, som grundigt vendte op og ned på de nedarvede romantisk-nationale synspunkter i det 19 . århundredes folkelige Danmarkshistorier. Koppel omtalte også udførligt og med sympati Arups skildring af syfilisens betydning for europaisk kønsmoral og

\footnotetext{
${ }^{19}$ Ladewig 1978, s. 160 note 74 . Inga Floto: Erik Arup og hans kritikere. Historisk Tidsskrift bd. 78,1978 , s. $4^{86}$ note 35 .

${ }^{20}$ Gunhild Agger m.fl.: Dansk litteraturhistorie bd. 7, Gyldendal 1984, s. 84 .

${ }^{21}$ Berlingske Tidende 8/10 1932.
} 
bogens fremstilling af den lutherske ortodoksis sejr i det 17 . århundrede, afsnit hos Arup med udpræget antiklerikal tendens.

Overordnet fandt Koppel, at „den moderne Historiker“ så de politiske begivenheder som udtryk for de økonomiske brydninger i samfundet, og at Arup for så vidt var i slægt med „marxistisk Historieopfattelse“. I det udgivne bind skildrede han samspillet mellem den væsentlig af sociale og økonomiske love determinerede udvikling og de store personligheders virke. Til at skabe en betydelig historieskriver hørte "fuldkommen Fordomsfrihed og Hensynsløshed og den mest komplette Ligegyldighed for Folks uklare Følelser og for den Fornærmethed“, man udsatte sig for, når man stødte folks patriotiske følelser. Tidligere havde man set historieskrivningens opgave i at styrke patriotismen. $\mathrm{Nu}$ havde man vel opgivet denne teori om den egne nations overlegenhed over for alle andre, der også for Danmarks vedkommende var noget vanskelig at opretholde i længden. Men desværre var ikke alle „Forfalskningerne", hvortil denne indstilling havde givet anledning, helt forsvundet endnu, skønt det skulle indrømmes, at Arup ryddede bravt op. Han havde fornyet historieskrivningen i Danmark, sluttede Koppel.

Uvejret brød løs med Henning Kehlers anmeldelse, en dobbeltkronik i Berlingske Tidende 4 . og 5 . oktober, en af de mest personligt fornærmende på dansk i nyere tid. Den førte til et par dramatiske hændelser, hvor politiet blev involveret, hvad aviserne skrev en hel del om det efterår. Hovedpersonen for den megen polemik opholdt sig på ferie i udlandet hele oktober måned og kommenterede tørt postyret fra London 8. oktober i et telefoninterview med Ekstrabladet: „Der findes mange Ord i det danske Sprog, og Hr. Kehler har Lov til at bruge dem allesammen".

Kehlers overfald sættes også i relief af den anmeldelse, den konservative journalist Franz v. Jessen fremkom med i Dagens Nyheder. Han var kritisk over for mange af bogens holdninger og synspunkter. Arup var for overmodig og selvsikker, drevet af lyst til at sige „tværtimod“. v. Jessen sluttede imidlertid sin anmeldelse med at betegne bogen som „et Værk, der ofte udfordrer til Modsigelse, men som rummer en mægtig Viden og vrimler af tankevækkende Synspunkter. Man vilde nødig undvære det i dansk Litteratur". Efter omstændighederne var det naturligvis en stor anerkendelse.

Kehler konstaterede til indledning, at det i 1 . bind af Danmarkshistorien havde været Arups plan at skrive en "folkelig Danmarkshistorie" $\mathrm{i}$ den forstand, at den på forhånd udvalgte „fredsommelige og 
arbejdsomme Hr. Middelmand" skulle være fremstillingens hovedperson, mens de „mere heroiske Personligheder“ skulle "skares ned til Sokkeholderne“. 1 . bind havde været „en radikalistisk-socialistisk Historiefortælling med en indskrænket Partimands skyldige Hensyn til Odenseprogrammet, Husmandsvælgerne, P. Munch og den økonomiske Historieopfattelse (Karl Marx). "Af denne plan var der i 2. bind kun „Vragstykker“ tilbage. I dette bind var Arup i det store og hele faldet tilbage på den politiske historie. Hovedvægten lå på „Forfatningshistorien“, som han ofrede helt unødigt meget plads på. Man mærkede tydeligt, at Arup havde været statsrådssekretær og aldrig havde forvundet det, men beholdt „en ubegavet Subalterns hele mystiske Benovelse overfor Ministermøder og Ministerbeslutninger og overfor Centraladministrationen, dette Væsnernes Væsen og Historiens Navle“. Men dette var kun „Skinhistorie“. Den rigtige historie opererede ikke med dokumenter, som alligevel ikke var det papir værd, de var skrevet på, men med „Livet“, med „Personerne“, „al Historieskrivnings første og sidste“. Men just „Dramaet i Historien“ lå langt uden for Arups evner og interesser. De eneste personkarakteristikker, han havde forsøgt sig med i 1 . bind, var dem, hvor kilderne ikke tillod det. Denne tendens havde han fortsat i 2 . bind som „Badutspringer“ ud fra den rigtige følelse, at her lå hans eneste chance for at vække opsigt.

Arup havde ofret mere tid på „Krigshistorien“ i 2. bind, end man ville have troet det muligt af ham. Nogen grund til at fordømme „danske Kongers offensive Krigspolitik"var der dog ingenlunde, indvendte Kehler. Arup anede ikke engang problemet, nemlig fortyskningen. Hvis danske konger havde afholdt sig fra forsøget på at udstrække deres magt og indflydelse over Østersøen og Nordtyskland, var det tilladeligt at mene, at resultatet var blevet „en aldrig hvilende Offensiv Syd fra, som vel kunde have hidført Undergangen for alt, hvad der er dansk: Riget, Monarkiet, Sproget, Nationen“.

Hvis Arups måde at skrive historie på vandt bifald, kunne „enhver stud. mag. med Skrivekløe“ eller „en fuld Chauffør" i sin fritid også skrive Danmarkshistorie. Arup var „en stortalende Gegensprecher", der kun var ude på at vakke sensation. En „demagogisk Historieskriver, som har hægtet sig fast i Enden paa et Par lokale politiske Partier. Derom vidner mangt og meget i hans Bog, der svarer til de højtravende Dedikationer, som fattige Poeter og Skribenter i gamle Dage anbragte foran i deres Bøger, til fyrstelige Personer, der var deres Mæcener. 'Fremskridtet' bestaar i, at en Ansøger til Understøttelser, Embeder, Ben, Mandater og hvad andet Demokratiet kaster af sig, i vor Tid 
serverer sine underdanige Skrabud ikke paa en særlig Side, som man kan rive ud eller springe over, men rundt om i Teksten paa de mest uformodede Steder. Læeren er haabløst prisgivet denne Form for Spytslikkeri“. Såvidt Kehler.

Indledningen til Albert Olsens anmeldelse i Social-Demokratens kronik 13/10 formede sig som et skarpt angreb på Aage Friis for at have stået bag Kehlers anmeldelse med dens „usædvanlig beskidte Toner“ og de mange angreb, der i de forløbne syv år var blevet rettet mod Arups Danmarkshistorie. Aage Friis erklærede dette for „usandt " og „systematisk Bagvaskelse" i indlæg i Politiken og Social-Demokraten $15 / 10$, hvortil Albert Olsen replicerede, at han stod ved, hvad han havde sagt, og at Aage Friis var velkommen til at lægge sag an (Social-Demokraten 16/10). Kehler selv stemplede endelig Olsens påstand som „Opspind“ og „Udslag af fræk Skadelyst" (Kristeligt Dagblad 1/11).

Albert Olsen mente, at angrebene på Arups Danmarkshistorie måtte skabe sympati for ham i „de brede Befolkningslag“, handlende, håndværkere, bønder og arbejdere, som Kehler i „det konservative Folkepartis Organ" omtalte med så stor foragt. Ved skæbnens ugunst, ville „Demokratiets Modstandere“ sige, var interessen for „Folkets Historie“ vokset samtidig med, at den var aftaget for „den individualistiske Historieskrivning“. Historien var blevet „en social stærkt økonomisk betonet Disciplin“. Denne historieopfattelse havde Socialdemokratiet ikke patent på, omend Karl Marx havde præget den, den deltes også af konservative udenlandske historikere. Arup var derfor i god kontakt med sin tid, selv om han derved kom i konflikt med den traditionelle personcentrerede danske historieopfattelse. I sin søgning mod den historiske sandhed havde Arup heller ikke kunnet undgå at omstøde meget, som „nationalistisk dansk Tradition “ havde kanoniseret, og dette kunne ikke gøres uden at støde „Reaktionen“. Arup havde givet en historisk fremstilling med en social indstilling, der ikke delte folk op i „ophøjede Personer" og ,middelmaadigt Pak“, der ikke var omtale værd eller højst fortjente overbærende forståelse. Middelalderens historie havde fået en social baggrund, som tidligere fremstillinger havde manglet. Albert Olsen roste i øvrigt bogens behandling af den økonomiske og politiske udvikling. Arup skildrede levende de politiske brydninger mellem kongemagt og stormæend, „maaske noget for levende“, fordi kilderne på en række områder ikke var særlig oplysende. Af „Smaating“, man kunne indvende, nævnede han, at Arup formentlig overvurderede valutapolitikens betydning i en overvejende naturaløkonomi, at han 
behandlede bondestandens kår for generaliserende, og at gennemgangen af forfatningshistorien var lidet overskuelig.

I en kronikanmeldelse i Kristeligt Dagblad gav Paul Holt 2. bind af Danmarkshistorien en hård kritik under overskriften „Et Tilbageskridt i Historieskrivningens Historie“. Med mange og overbevisende eksempler godtgjorde han, at værket prægedes af antimonarkiske, antinationalistiske, antimilitaristiske og antiteologiske tendenser. Værkets „materialistiske Grundopfattelse“ var ikke gennemført konsekvent, idet forfatningens og administrationens historie fik langt mere plads end erhvervslivet. Kun for åndslivets vedkommende var Arup nogenlunde konsekvent, det var behandlet stedmoderligt, reformationen uforstående og misvisende.

\section{Ideologiske hovedspørgsmål}

Arups Danmarkshistorie satte mellemkrigstidens problemer under debat. Arup „flyttede Nutiden over i Fortiden “, som Poul Johs. Jørgensen skrev til ham i et privatbrev, efter dennes mening ,i altfor høj Grad “. ${ }^{22}$ Det var Arups stærke modernisme, hans trang og vilje til at se og vurdere fortiden i nutidens lys, der affødte polemikken i dagspressen. Dagbladsdebatten domineredes i overvejende grad af anmeldernes holdning til Danmarkshistoriens politiske og ideologiske tendens og implikationerne heraf for historiesynet. Omkring forsvarsspørgsmålet samler sig et helt problemkompleks. Jørgen Olrik karakteriserede Arup som „Antikrigshistoriker" med en "pacifistisk Synsmaade“, Hans Jensen og Henning Kehler betegnede ud fra hver deres standpunkt Arup som af- eller nedrustningstilhæenger. Kehler og Harald Nielsen gik videre og satte Arups holdning i relation til udenrigspolitikken og forholdet til Tyskland. Forsvarskompromisset mellem regeringen og Venstre i marts 1932 indeholdt nedskæringer i et sådant omfang, at forliget ,var meget nær Det radikale Venstres 1905-program, der talte om et grænse- og søpoliti. Fra 1932 var det kun muligt for det danske forsvar at markere en krænkelse af vor neutralitet, men det var ude af stand til at tage en egentlig kamp op."Ved den tyske besættelse af Danmark 9. april 1940 tilbød udenrigsminister P. Munch om morgenen samme dag at gå af. ${ }^{23}$ Arup, og Det radikale Venstre, oplevedes i konservativt sindede kredse

\footnotetext{
${ }^{22}$ Poul Johs. Jørgensen til A. 5/7 1926.

${ }^{23}$ Tage Kaarsted: Krise og krig 1925-1950. Gyldendals og Politikens Danmarkshistorie bd. 13,1991, s. 44 f., 212.
} 


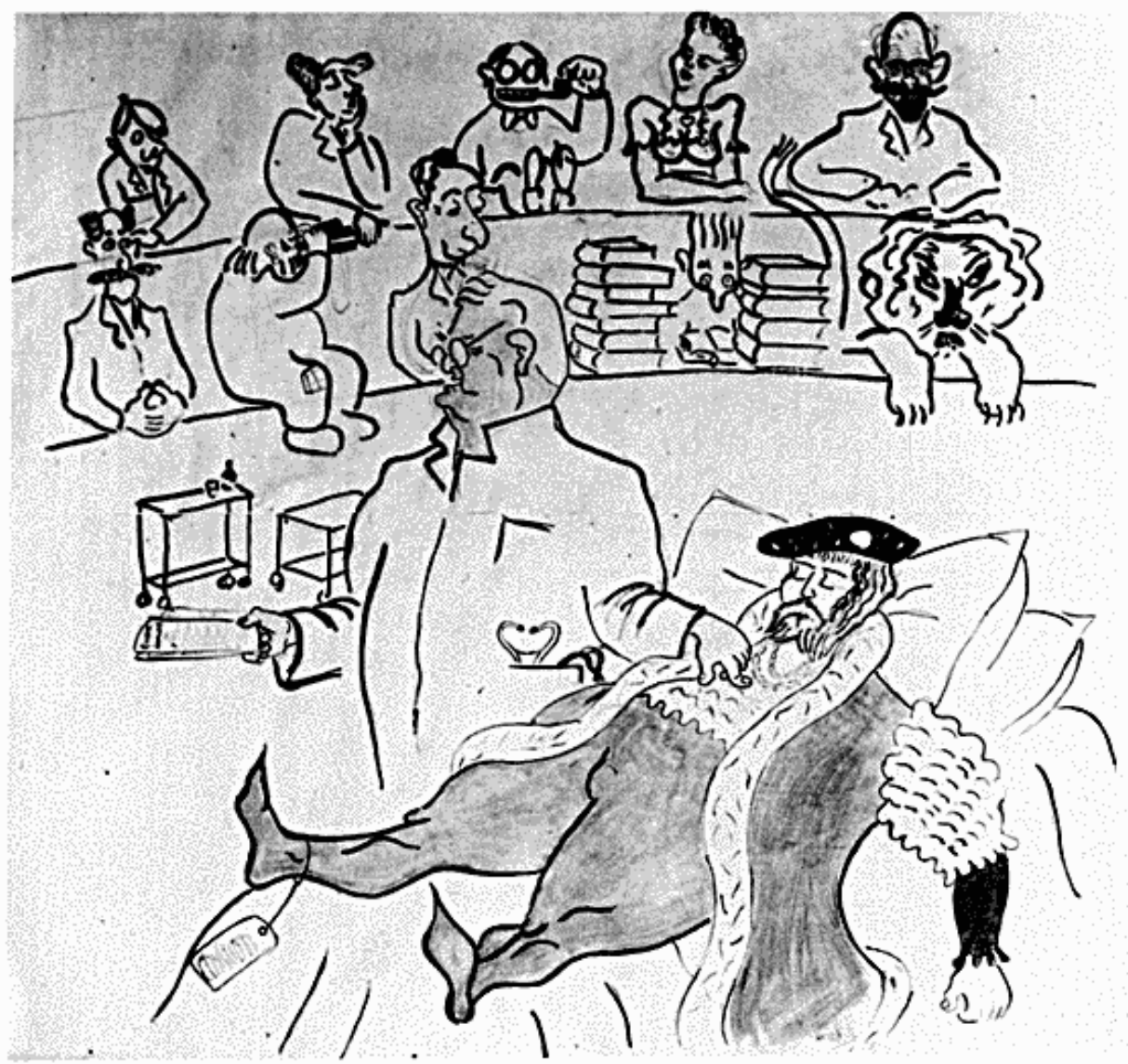

Theatrum anatomicum eller Christian II under obduktion. Tegning udført af stud.med., senere overlage Jens Erik Boje Rasmussen til afskedsfesten for Arup 30/11 1946 på Studentergården, hvor Arup $\mathrm{i}$ over 20 år var en afholdt efor.

som tyskvenlige; Nordslesvigs tilbagevenden til Danmark i 1920 blev set som et nederlag for partiets udenrigspolitiske synspunkter. Herfra var springet for konservative ikke langt til at betragte Arup som u- eller antinational. Harald Nielsen talte om „Forræderiet“. Obersten og militærhistorikeren Rolf Kall sagde tilsvarende, omend mere slebent, at man ikke få steder kunne komme i tvivl om, hvorvidt Arup var født „denne eller hinsides Ejderen“. Arups fremstilling pregedes dybt af hans „Forsvarsnihilisme “. ${ }^{24}$ Kall anmeldte 1. bind af Danmarkshistorien over tre kronikker i begyndelsen af februar 1926 i Nationaltidende, der

${ }^{24}$ Nationaltidendes kronik $5 / 21926$. 
altså ofrede ikke mindre end otte kronikker på én måned på at bekæmpe Arup. Lis Jacobsens skarpe angreb måneden i forvejen har givet hans konservative antagonister blod på tanden. Nationalfølelsen var for Arups konservative modstandere knyttet til den militære hæudelse af landets selvstændighed og kongemagten. Hertil kom, at når Arup fremstillede Absalon som en på bunden af hans sjæl jordgrisk sjællandsk godsejer - de radikales hovedmodstandere under Forfatningskampen i forrige århundrede (!) - og tilsvarende omvurderede andre stormænds indsats i Danmarks historie, så oplevedes det som sårende og truende for nationalfølelsen af konservative kredse. „Aandelig Afrustningspolitik af den mest skxebnesvangre Art" kaldte Agnes SlottMøller det i en kronik i Berlingske Tidende (16/2 1926). Arup, og med ham også Albert Olsen, Vald. Koppel og anmelderen i Arbejderbladet, så derimod $\mathrm{i}$ en bestemt form for nationalfølelse en mulig krigsårsag: „Nationalisme kalder vi den afart af den naturlige, medfødte fæedrelandskærlighed, der er bestemt ved en levende bevidsthed om modsætningsforholdet til et andet folk, hvilken efter omstændighederne kan stige til en blandet følelse af had, foragt, skjult beundring og frygt" ${ }^{25}$ Problemet var blot, at Arups modstandere trak grænsen mellem „den naturlige, medfødte fæedrelandskærlighed“ og "nationalisme“ anderledes end ham. Arups syn på kongemagten er mere kompliceret, end det har kunnet beskrives i denne artikel. Som ung havde Arup oplevet Christian IXs modstand mod folketingsparlamentarismen og som moden mand Christian Xs indgreb i Påskekrisen 1920, hvad man tør antage, har påvirket hans holdning. Sin mening om den danske kongemagts stilling og opgaver har Arup sagt i 2. bind af Danmarkshistorien i forbindelse med Margrete $\mathrm{I}^{26}$

Det smukkeste træk ved Arups Danmarkshistorie er de sociale og folkelige holdninger, der gennemtrænger fremstillingen, og som må ses på baggrund af mellemkrigstidens Danmark med de stærke modsætninger mellem over- og underklasse, rig og fattig, arbejdere og småfolk. Disse synspunkter var stærkt tilstede i dagbladsdebatten, kraftigst fremhævet i Arbejderbladel og af Albert Olsen i Social-Demokraten, bekæmpet af Harald Nielsen og Henning Kehler og af dem forbundet med foragt for demokrati og parlamentarisme.

I denne sammenhæng skal Arups „materialistiske historieopfattelse“ også anskues, som næsten alle hans anmeldere hæftede sig ved, og som

${ }^{25}$ DH II, s. 8 o.

${ }^{26} \mathrm{DH}$ II, s. 185 f. 
alle, på nær Albert Olsen, betegnede som „marxistisk“, hvad den ikke var. ${ }^{27}$ I Arups Danmarkshistorie havde den økonomiske udvikling, særligt bondens og borgerens arbejde, fået en plads som ikke før ud fra den tanke, at disse forhold var vigtigere for den politiske udvikling end åndelige verdier. ${ }^{28}$ Det mest overraskende ved reaktionerne er, at dette historiesyn blev så bredt accepteret i dagbladskritikken, som det gjorde. Også Henning Kehler og Harald Nielsen tillagde det faktisk relativ værdi. Hvad de, men vel at mærke også Lis Jacobsen og i nogen grad Jørgen Olrik bebrejdede Arup var, at han nivellerede Danmarkshistorien ved at „tophugge“ de store personligheder.

Partipolitisk delte debatten omkring Arups Danmarkshistorie sig efter de linjer, man kunne forvente: på den ene side Det Radikale Venstre, Socialdemokratiet og kommunisterne, på den anden side Konservative og Venstre.

\section{Perspektiv}

I dagbladskritikken oplevedes Arups Danmarkshistorie som et voldsomt brud med det 19 . århundredes national-romantiske historieopfattelse i de folkelige Danmarkshistorier: Frederik Barfods Fortellinger af Fadrelandets Historie (1853, kom i fire oplag) og Adam Fabricius' Illustreret Danmarks Historie for Folket $(1854-55), 4$. oplag $1914^{-1} 5$ ved sønnen og Arups professorkollega Knud Fabricius.

På den baggrund må modtagelsen i de grundtvigske tidsskrifter vurderes som meget liberal: Man anerkendte overalt værdien af det meget nye stof, Arup fremlagde, især på det økonomiske og sociale område, og den relative værdi af værkets mange nye synspunkter, men lagde forståeligt nok mere eller mindre afstand til Arups livssyn og materialistiske historieopfattelse. ${ }^{29}$

De videnskabelige anmeldelser i fagtidsskrifterne af Arups Danmarkshistorie (Ellen Jørgensen, Poul Johs. Jørgensen, Knud Fabricius

\footnotetext{
${ }^{27}$ Birgitta Odén: Det moderna historisk-kritiska genombrottet i svensk historisk forskning, Scandia bd. 41.1, 1975, s. 19 .

${ }^{28}$ Jfr. $D H$ II, s. $59^{6}$.

29 Bavnen, Borups Hojskole, Dansk Udsyn og Hojskolebladet. I de egentlige skoletidsskrifter: Den danske Realskole, Folkeskolen, Hjem og Skole, Kobenhauns Kommuneskole og Vor Ungdom blev Danmarkshistorien generelt positivt anmeldt; jfr. også privatbreve til Arup fra F.C. Kaalund-Jørgensen 10/10 1925 og Hans Kyrre 25/11 og 16/12 1932.
} 


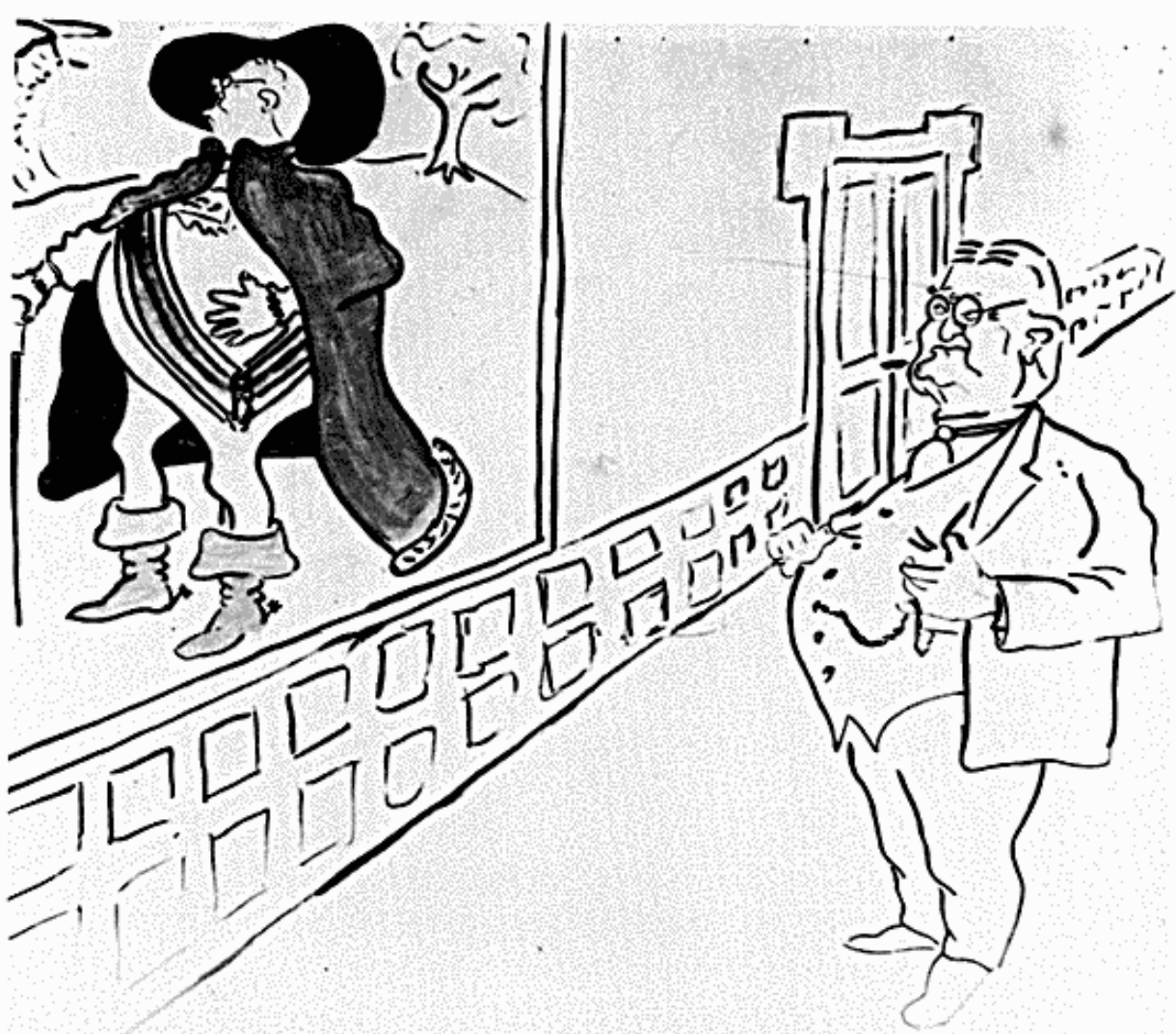

Drømmer Arup om gods og adelskab som historiografens velfortjente løn?

og Poul Nørlund), som Inga Floto har behandlet, ${ }^{30}$ må af pladshensyn lades uomtalt, herunder spørgsmålet om, hvorvidt kritikken ydede Arup retfærdighed. Der er ingen tvivl om, at Arup selv følte sig dybt skuffet, men alligevel har han bevaret troen på, at hans Danmarkshistorie havde fremtiden for sig. Begge reaktioner kommer til udtryk i den lille selvbiografi, der indleder artiklen. Formentlig var det kritikken også af 2. bind, der var hovedårsagen til, at Danmarkshistorien forblev en torso. Dette bind affejede Knud Fabricius (for det 16. århundredes

${ }^{30}$ Floto ${ }_{197} 8$, særligt s. $484-93$. Ang. Poul Johs. Jørgensens anm. jfr. også hans brev til A. $5 / 719^{26}$, der ligger i forlængelse af Flotos vurdering af kritikken. 
vedkommende) som „et svagt Arbejde“ og spåede, at forskningen ville komme til at gå uden om værket, ${ }^{31} \mathrm{i} \emptyset$ vrigt kun for nogle få år senere at give en nazistisk Danmarkshistorie et anbefalende ord med på vejen, med klar adresse til Arup. ${ }^{32}$

Det er arven fra Georg Brandes og Viggo Hørup, der videreføres i Arups Danmarkshistorie, når det gaelder livs- og samfundssyn. Arups forhold til Viggo Hørup kommer frem i den bog af samme navn, Politiken udgav $1941 \mathrm{i}$ anledning af hundredårsdagen for Hørups fødsel. Om Georg Brandes har Arup udtalt i en enquête, samme blad bragte på hundredårsdagen for Brandes' fødsel $4 / 2$ 1942, at „for tusinder af modtagelige menneskesjale blev livet rigere og friere $\mathrm{i}$ glansen af hans flamme". Formodentlig har Arup endda skrevet sit bidrag med påholden pen, idet den tyske besættelsesmagt ikke ønskede ,jøden " og frigøreren Georg Brandes fejret. ${ }^{33}$ Mange af de indvendinger, der blev rettet mod Arups Danmarkshistorie i dagspressen fra konservativt hold, mødte også Brandes af den gode grund, at Henning Kehler og Harald Nielsen også førte an i den konservative kamp mod brandesianismen i mellemkrigstiden. ${ }^{34}$ Omvendt synes Georg Brandes tilsvarende at have haft både interesse og sympati for Arups arbejde. Oskar Johansen takkede i et brev Arup for tilsendelsen af 2. bind af Danmarkshistorien og føjede til, at han og Georg Brandes, i de sidste år Brandes levede, ikke sjeldent talte om, hvor gerne de ville opleve udgivelsen af Arups fortsatte Danmarks Historie, skønt de var klar over, at hans „revolutionære Behandling“ af det omfattende stof nødvendigvis måtte tage lang tid..$^{35}$

Essensen i Arups politiske syn kan bestemmes som „den stadige hævdelse af ligheden, saa vidt det til enhver tid har været muligt, i alt fald som afvergelse eller fjernelse af ulighed ${ }^{* 36}$ Om Arup hermed alene har tænkt på lige muligheder for enhver uanset stand, altså rettighedsliberalisme, men derimod ,ikke just på lighed i økonomiske

${ }^{31}$ Historisk Tidsskrift 1o. rk. II, 1933, s. 369 .

${ }^{32}$ John T. Lauridsen: „Nu gjalder luren“. Fortiden i DNSAP's tjeneste, Fund og Forskning bd. 32,1993 , s. 172 med note 66 .

${ }^{33}$ Elias Bredsdorff: Kommer det os ved?, 1971, s. 34-36.

${ }^{34}$ Olav Harsløf: Den konservative myte om Georg Brandes og „det moderne gennem-

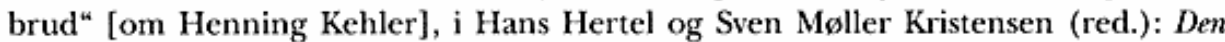
politiske Georg Brandes, 1973, s. 157-81.

${ }^{35}$ Oskar Johansen til A. 1/10 1932.

${ }^{36} \mathrm{DH}$ II, s. $39^{6}$. 
kår “, som Povl Bagge mente, ${ }^{37}$ er en lille diskussion værd, fordi Arup andetsteds har skrevet indforstået om samfundsfølelsens etiske værdi. ${ }^{38}$

Arups Danmarkshistorie kom i én forstand på rette tid: I 1924 dannede Stauning Danmarks første socialdemokratiske regering, der holdt til december 1926, med Det Radikale Venstre som støtteparti, og i 1929 indledte de to partier det regeringssamarbejde, der kom til at vare hele 11 år. Men ,arbejdet" og „den danske bonde“, de centrale størrelser, Arup ville bygge sin Danmarkshistorie op omkring, var i mellemkrigstiden mindre entydige begreber, end værket lagde op til. Inga Floto har gjort opmærksom på, at „kernen til Arups egen historieopfattelse" skal findes i Hørup-bogen: Hørup ville, at den danske bonde skulle danne kernen i et bevidst, rationelt demokrati. Oprindelig var Hørup tilbøjelig til at mene, at „Bondens Tankegang“ i det store og hele faldt så temmelig sammen med hans egen, senere kom han i tvivl, „og da han 1901 for sidste Gang tager Spørgsmålet frem, er han blevet så uvis om Svaret, at han endog, hvad der er højst usædvanligt hos ham, anmoder den historiske Forsker om Hjælp“, siger Arup her. ${ }^{39}$ „Det blev Arups livsopgave at give dette svar", bemærker Floto. ${ }^{40} \mathrm{Ja}$, Arup sendte 1. bind af sin Danmarkshistorie til J.C. Christensen, der allerede var moderationens mand i forhold til Hørups gamle kampfælle C. Berg. ${ }^{41}$ Imidlertid var den danske bondes og det danske landbrugs førstemand i mellemkrigstiden ikke J.C. Christensen, men Thomas Madsen-Mygdal, statsminister i Venstre-regeringen 1926-29, som ,af frygt for kommunismen " svingede over i "tyskvenlighed “ under besættelsen. ${ }^{42} \mathrm{Og}$ hvor meget perspektiv var der for Arup i Madsen-Mygdals ,lad falde, hvad ikke kan stå"-liberalisme? Hans Jensen anmeldte Arups Danmarkshistorie meget positivt, og hertil kan lægges en anerkendende anmeldelse af Caroline Emilie Andersen i Fyns Venstreblad; men herpå tør man næppe lægge for megen vægt, når det gælder holdningerne $\mathrm{i}$ Venstre-kredse i almindelighed. Begge stod Arup nær. Mere betegnende er, hvad Dagens Nyheder kunne berette 24. oktober 1932, at i en række af partiet Venstres større blade gjordes striden om Arups Dan-

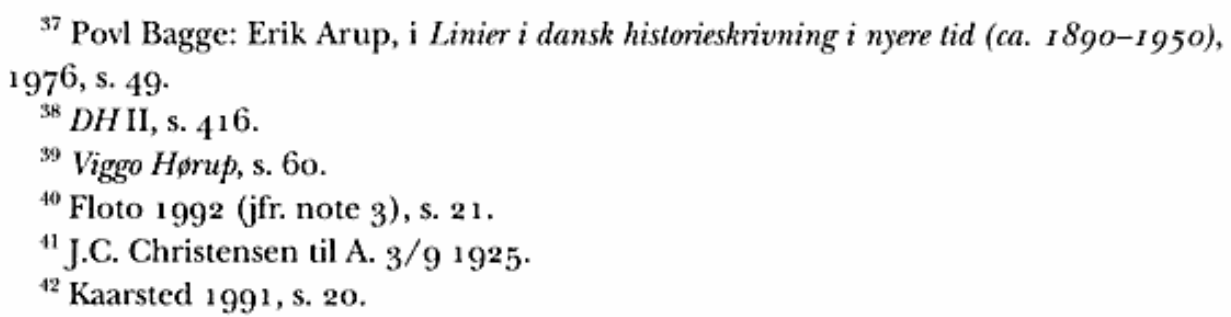


markshistorie til genstand for den betragtning, at det i anledning af de vedholdende angreb på Arups historieskrivning for at vare politisk tendentiøs og uvidenskabelig fra Københavns Universitets side på betryggende måde burde fastslås, „om denne Universitetslærer arbejder paa videnskabelig forsvarlig Grund eller ikke“.

I sin nekrolog over Erik Arup skriver C.O. Bøggild-Andersen, at Arups to bind Danmarkshistorie trods deres mangler er „et storværk i nordisk historieskrivning og i dansk aandshistorie". ${ }^{43}$ Til værkets fortjenester hører også Arups stil. Den er vel grundlæggende fast og klar, nøgtern og saglig, men har let, som det er blevet sagt, til lune og ironi, patos og indignation. Erik Arup har imidlertid selv på et bestemt sted et bestemt tidspunkt fundet et dækkende udtryk for den. I hans arkiv findes et af Poul Henningsens berømte revyvers fra en avis, der indeholder en hyldest af denne til skuespilleren Olga Jensen ved en fest $\mathrm{i}$ anledning af en P.H.-revys jubilæum. ${ }^{44}$ Arup har klippet verset ud og limet det op på et ark $\mathrm{i}$ overskåret kvart $\mathrm{og}$ med blak nedenunder skrevet en lille personlig notits i hånden:

"Jeg elsker den varme, den store og stille og helt ud beherskede Stil, Besværet er væk, man har naa't, hvad man vilde, og alt synes gjort i et Smil.

Vi andre, vi kender det Slæb, som gaar foran, vi véd, ingen Nerve er slap, naar Salen skal samles i én Haand som én Mand, og Verden bliver hipper som hap."

„Fra sommeren 1931“, tilføjer Arup, „da jeg sad hjemme og arbejdede med fortvivlet stædighed paa II. bind af Danmarkshistorien. Dette simple revyvers var mig til stor trøst; det udtrykte helt rigtigt, hvad jeg tilstræbte“.45

\footnotetext{
${ }^{43}$ Oversigt over Videnskabernes Selskabs Virksomhed 1951-52, s. 120.

" PH-revyen Riddersalen 1931, jfr. Poul Henningsen: Vers til idag. Et udvalg redigeret af Sven Møller Kristensen, 1966 , s. 14 f.

${ }^{45}$ Arups arkiv (Personalia).
} 


\section{BILAG}

Artiklen bygger på gennemgang af flg. anmeldelser:

Arups arkiv: VIII 1 b (bd. 1) og VIII 1 f (bd. 2). Anmeldelser, der ikke findes heri, er mærket med *.

Bind I: A.G. Andersen: Folkeskolen, årg. 42, nr. 38, $17 / 91925$, s. 648 f.; Caroline Emilie Andersen: Fyns Venstreblad 18/9 1925 (kronik); E. Bremerstent: Lasning, nr. 1, jan. 1926, s. 12-1 7; *Edv. Bull: (no.) Historisk Tidsskrift, 5 . rk. VII, 1927, s. 125-34; Gunnar Carlquist: Svenska Dagbladet Snällposten 8/12 1925; E[rnst] [Christianse]n: Arbejderbladet 9/4 1926; Povl Engelstoft: Sorø Amtstidende 16/9, 17/9 1925 (kronikker); Kr. Erslev: Politiken ${ }_{15} / 919^{25}$ (kronik); *Knud Fabricius: Nordisk Tidskrift för Vetenskap, Konst och Industri. Ny Serie I, 1925 , s. 574-87; H.H.: Frederiksborg Amts Avis $7 / 111925$; S[igfred] H[ansen]: Akademisk Ungdom, årg. 7, nr. 13, 1/2 1926 (upag.); Elna Hoffmeyer: Nordsjellands Venstreblad 31/10 1925; Hans Høffding: Gads Danske Magasin, årg. 19, $19^{25}$, s. 593-604; N.P.J.: Vendsyssel Venstreblad $21 / 9$ 1925; Lis Jacobsen: Politiken 22/1, $23 / 1,25 / 1,27 / 1 \log _{17} 7 / 5^{1926}$ (kronikker, også optrykt i sammes *Tolv Epistler, 1928); Hans Jensen: Kobenhavn 26/9 $19^{2} 5$ (kronik); Johs. V. Jensen: Social-Demokraten 23/11, 24/11 1925 (kronikker), også i Tidens Tegn (Oslo) 30/11 1925; Finnur Jónsson Politiken $11 / 51926$ (kronik), 20/5 1926; *Ellen Jørgensen: Historisk Tidsskrifl, 9. rk. IV, 1926, s. 285-97; *Poul Johs. Jørgensen: smst., s. 297-351; F.C. [Kaalund]-Jørgensen: Kobenhavns Kommuneskole, årg. 18, nr. 32, 8/10 1925, s. 289-91, med andringer i Den Danske Realskole, årg. 27, nr. 22, $15 / 111925$, s. $3^{6} 5^{-68}$; Rolf Kall: Nationaltidende $4 / 2$, 5/2, 7/2 1926 (kronikker); Henning Kehler: Kristeligt Dagblad 21/11, 25/11 1925 (kronikker, også optrykt i sammes * Overmennesker og Andre, 1929); Hal Koch: Berlingske Tidende 7/12,8/12 1933 (kirkehistoric); K[nud] K[nudsen]: Hjem og Skole, årg. 18, dec. $19^{25}$, s. 223-29; Marius Kristensen: Højskolebladet, årg. 5o, nr. 43, 23/10 1925, sp. 1361-64 (polemik med Arup sp. 1455-62, 1519-23); Svend Larsen: Fyns Tïdende 30/11 1925; M[ichael] Neiiendam: Helsingors Avis 8/12 1925; Harald Nielsen: Nationaltidende: 12/2, 13/2, 15/2, 1 7/2 og 18/2 1926. Også i *Dagens Nyheder 13/2, 14/2, 16/2, 18/2 og 19/2 1926 (kronikker). Desuden i Radikal Videnskabelighed, 1926 og * Selvforsvar og Landevarn, 1927; *N.C. Nielsen: Borups Hojskole, årg. 11 , nr. 6, 1 /3 1926, s. 243 f.; Den Nye Litteratur, ărg. 3, nr. 2, 15/10 1925, s. 45; Jørgen Olrik: Ribe Stifts-Tidende 14/9 1925 (kronik); Albert Olsen: Social-Demokraten: 24/9 1925 (kronik); Léon Pineau: Rerne critique d'histoire et de littérature no. 9, 1 er mai 1926, s. 168-171; Cai Schaffalitzky de Muckadell: Berlingske Tidende 26/2 1926; Agnes Slott-Møller: Berlingske Tidende $15 / 2$, $16 / 21926$ (kronikker); Viggo Starcke: Det Frie Blad, årg. 5, nr. 47, $21 / 11$ $19^{25}$, s. 651 f., nr. 48, 28/11, s. 668 f.; Studium-Ugeblad for Studerende $4 / 111925$, s. 7 ; *(Sv.) Historisk Tidskrift, XLVI, 1926, s. 73-75.

Bind II: *Jørgen Bukdahl: Dansk Udsyn, årg. 13, 1933, s. 173-75; *A. Drewsen Christensen: Hjem og Skole, årg. 26, jan. 1933, s. 35-40; Gunnar A. Engberg: Ollerup Folkehojskoles Aarsskrift 1932, s. 89 f.; Povl Engelstoft: Bogens Verden, årg. 14, nr. 11 , nov. 1932, s. 237 f.; *Knud Fabricius: Historisk Tidsskrift, 1o. rk. II, 1933, s. 323-69. Tilleg smst. 1934, s. 554 f.; Sven Grauers: Göteborgs Handels- och Sjöfartstidning 19/12 1932; B.R.H.: Vi Gymnasiaster, årg. 4, nr. 9, april 1933, s. 11 ; „Hitsor ${ }^{4}$ : Ekstrabladet $5 / 101932$; 
Paul Holt: Kristeligt Dagblad 29/10 1932 (kronik); A.Th.J.: Berlingske Tidende $11 / 12$ $193^{2}$ (kirkehistorie); Franz v. Jessen: Dagens Nyheder 2/10 $193^{2}$ (kronik); Henning Kehler: Berlingske Tidende 4/10,5/10 $193^{2}$ (kronikker); Vald. Koppel: Politiken 2/10 $193^{2}$ (kronik); Marius Kristensen: Højskolebladet, årg. 57, nr. 44, 28/10 1932, s. 653 f.; H[ans] K[yrre]: Vor Ungdom, årg. 54, dec. 1932, s. 314-23; *Anton Mikkelsen: Bavnen, årg. 29 , nr. $43,27 / 10193^{2}$, s. $85^{1-5} 8$, nr. $44,3 / 11193^{2}$, s. $89_{1-98}$; Carl Lindberg Nielsen: Ribe Amts-Tidende $21 / 10,22 / 101932$ (kronikker); *Ingvard Nielsen: Folkeskolen, årg. 49, nr. 48, 1/12 1932, s. 766-68; Albert Olsen: Social-Demokraten 13/10 $193^{2}$ (kronik); Karl Rasmussen: Dagens Nyheder 23/4 1934 (kronik). Samme: *Bavnen, årg. 34 , nr. 5o, $16 / 121937$, s. $789-94$, ảrg. 35 , nr. 3 , 20/1 1938, s. $39-43$, nr. 5, 3/2, s. $73-76$, nr. $6,10 / 2$, s. 89-92, nr. 12, 24/3, s. 177-82. Delvis ogsả i *Folkeskolen, årg. 54, nr. 43, 28/10 1937, s. 823-26, årg. 55, nr. 22, 2/6 1938, s. 444 f.; C.L. Skjoldbo: Rød Ungdom, nr. 11, nov. 1932, s. 117 , 119 ; Fridlev Skrubbeltrang: De Nye Bøger, årg. 2, dec. 1932, s. 166-69; *Curt Weibull: Scandia VI, 1933, s. $116-24$; Frantz Wendt: Studenterbladet 26/10 1932. Samme: Herlovianeren, årg. 10, nr. 5, dec. 1932, s. 37 f. (om Herluf Trolle).

\section{SUMMARY}

\section{Thyge Svenstrup: The critical reception Erik Arup's history of Denmark}

The name and renown of the historian Erik Arup (1876-1951) is particularly linked to his (incomplete) Danmarks Historie (vol. 1 and $219^{2} 5-32$, vol. 3 posthumous? 1955). Arup broke with the national historical tradition in this work, which he based on systematic critical use of the sources and a materialistic view of history. This article investigates the reception of his history of Denmark in the daily press and uses materials in Arup's hitherto inaccessible archive. A member of the political party the Radical Venstre [Radical Left], Arup extended the ideas of the politician Viggo Hørup and the critic Georg Brandes. Arup's conservative opponents correctly pointed out that his history was pervaded by anti-monarchist, anti-nationalist, anti-militarist and anti-clerical tendencies. Arup was in favour of Danish disarmament because of relations with Germany. Conservatives found this policy to be dangerous and undermine national feelings. Arup's description of societal development was influenced by his ideals on social issues, democracy and popular culture. The sharp-toned debate in the newswpapers divided along political party lines between the Radicals, the Social Democrats and the Communists on one side, and the Conservaatives and Liberals (Venstre) on the other. 